\title{
Diallylpolysulfides induce growth arrest and apoptosis
}

\author{
CORINNA BUSCH ${ }^{1}$, CLAUS JACOB ${ }^{2}$, AWAIS ANWAR ${ }^{2}$, TORSTEN BURKHOLZ ${ }^{2}$, LALLA AICHA BA ${ }^{2}$, \\ CLAUDIA CERELLA ${ }^{3}$, MARC DIEDERICH ${ }^{3}$, WOLFGANG BRANDT ${ }^{4}$, \\ LUDGER WESSJOHANN $^{4}$ and MATHIAS MONTENARH ${ }^{1}$
}

\author{
${ }^{1}$ Medizinische Biochemie und Molekularbiologie, Universität des Saarlandes, Gebäude 44, D-66424 Homburg; \\ ${ }^{2}$ Division of Bioorganic Chemistry, School of Pharmacy, Saarland University, Campus, D-66123 Saarbrücken, \\ Germany; ${ }^{3}$ Laboratoire de Biologie Moléculaire et Cellulaire de Cancer, Hôpital Kirchberg 9, \\ rue Edward Steichen, L-2540 Luxembourg, Luxembourg; ${ }^{4}$ Department of Bioorganic Chemistry, \\ Leibniz Institute of Plant Biochemistry, D-06120 Halle (Saale), Germany
}

Received October 5, 2009; Accepted November 27, 2009

DOI: 10.3892/ijo_00000550

\begin{abstract}
Garlic-derived organo sulphur compounds such as diallylsulfides provide a significant protection against carcinogenesis. Chemically synthesized, and highly pure diallylsulfides with a chain of 1-4 sulphur atoms, as well as a range of control compounds, were employed to investigate the influence of these agents on cell viability, cell cycle arrest and induction of apoptosis in HCT116 human colon cancer cells. Diallyltrisulfide, and even more efficiently diallyltetrasulfide treatment of HCT116 cells led to a reduced cell viability, cell cycle arrest and apoptosis. A similar activity was found for the propylanalogues, while mono- and disulfides were considerably less active. Initial calculations point toward the ability of triand tetrasulfides to form reactive oxygen species (ROS). Here, we found that the induction of apoptosis was indeed dependent on the redox-state of the cell, with anti-oxidants being able to prevent sulfide-induced apoptosis. Furthermore, using HCT116 cells which were either positive or negative for $\mathrm{p} 53$ revealed that p53 is clearly dispensable for induction of apoptosis. Growth arrest and induction of apoptosis is associated with a considerable reduction of the level of cdc25C. These results support the therapeutic potential of polysulfides and allow insight into the mechanisms based on the polysulfide biochemistry.
\end{abstract}

\section{Introduction}

It has been known for quite some time that garlic-derived organosulphur compounds such as diallyldisulfide provide a significant protection against carcinogenesis (1-6). In this context, animal studies and in vitro experiments provide evidence for an anti-carcinogenic effect of these natural

Correspondence to: Professor Mathias Montenarh, Medizinische Biochemie und Molekularbiologie, Universität des Saarlandes, Gebäude 44, D-66424 Homburg, Germany

E-mail: montenarh@uks.eu

Key words: diallylsulfides, apoptosis, redox reaction, cdc25C, p53, polysulfides, growth arrest ingredients against cancers of the stomach, colon, head and neck, lung, breast and prostate (reviewed in ref. 1). Furthermore, an anti-bacterial effect against Helicobacter pylori has been demonstrated for several ingredients of garlic (2).

Recent studies indicate that diallyldisulfide and, in some cases diallyltrisulfide, cause mitotic arrest in cancer cells (7-9). Interestingly, these organosulphur compounds do not only inhibit cancer cell proliferation but also appear to induce apoptosis in cancer cells, which apart from chemo-preventive aspects turns these agents into interesting lead structures for the treatment of already existing cancers (10-13).

There is now considerable interest in the underlying chemical and biochemical processes. Our present study, using synthetically generated and highly purified diallylsulfides to avoid any artefacts, has focussed on three closely related questions. First of all, we have tried to pinpoint the chemical characteristics required for biological activity using a range of sulfides and related compounds, such as propyl-analogues [i.e., the reduced allyl moieties, 1,6-heptadiene and 1,9decadiene for the isosteric replacement of the (oligo-) sulfide moieties]. We observed a distinct activity of tri- and tetrasulfides, which were fairly independent of the allyl- or propyl-group. At the same time, the rather low activity of mono- and disulfides confirmed the need for sulphur chain lengths of three or more. Secondly, we tried to identify cellular effector molecules by analyzing ROS formation. Since cdc $25 \mathrm{C}$ is required for $\mathrm{G}_{2} / \mathrm{M}$ transition and p53 is implicated in cell cycle arrest and induction of apoptosis, we thirdly analyzed the role of these two proteins on diallylsulfide-induced processes: p53 is clearly dispensable for induction of apoptosis. However, growth arrest and induction of apoptosis is associated with a considerable reduction of the level of cdc $25 \mathrm{C}$. These findings are of particular importance, since they provide a link between polysulfides, redox state, cell cycle arrest and induction of apoptosis.

\section{Materials and methods}

Cell culture, treatment and protein extraction. We used the p53-positive HCT116p53wt and the p53-negative 
HCT116p53-- cell lines (14), which were maintained at $37^{\circ} \mathrm{C}$ and $5 \% \mathrm{CO}_{2}$ in McCoy's 5A medium (PromoCell, Heidelberg, Germany) with $10 \%$ fetal calf serum (FCS). Diallylsulfides, dipropylsulfides, 1,6-heptadiene, and 1,9-decadiene were dissolved in DMSO to a 2000-fold stock solution, which was freshly prepared before use. Cells were seeded in 6-well plates and treated one day after seeding for the indicated times. $\mathrm{N}$-acetylcysteine and ascorbic acid were dissolved in $\mathrm{H}_{2} \mathrm{O}_{\text {dest. }}$ to a 2000-fold stock solution and given into the cell culture medium for $1 \mathrm{~h}$. Medium was removed before treating the cells with the compounds. Cells were harvested after removing the medium by adding $400 \mu 1$ trypsin/EDTA solution $[0.25 \%(\mathrm{w} / \mathrm{v})$ trypsin, $0.1 \%$ (w/v) EDTA], which was removed immediately. Cells were resolved in cold phosphate buffered saline (PBS, pH 7.4) and centrifuged together with the cell culture medium at $4^{\circ} \mathrm{C}$ and $250 \mathrm{x}$ for $7 \mathrm{~min}$. After one washing step with PBS, cells were resolved in 50-100 $\mu$ l RIPA buffer (50 mM Tris- $\mathrm{HCl}, \mathrm{pH} 8.0,150 \mathrm{mM}$ $\mathrm{NaCl}, 0.5 \%$ sodium desoxycholate, $1 \%$ Triton $\mathrm{X}-100,0.1 \%$ SDS) supplemented with the Protease Inhibitor Cocktail Complete $^{\mathrm{TM}}$ according to the manufacturer's instructions (Roche Diagnostics, Mannheim, Germany). After lysis, cell debris was removed by centrifugation. The protein content was determined according to a modified Bradford method with Bio-Rad reagent dye (Bio-Rad, München, Germany). Extracts were used for Western blot analysis.

Determination of viability. The viability of the cells was determined by a colorimetric MTT (3-[4,5-dimethylthiazol2-yl]-2,5-diphenyl-tetrazoliumbromide; Sigma) assay. Cells $\left(1 \times 10^{4}\right)$ were seeded in 24 -well plates in a final volume of $500 \mu 1$ medium. Four hours before the end of treatment, $50 \mu 1$ MTT $(5 \mathrm{mg} / \mathrm{ml}$ PBS) were added. The enzymatic reaction took place at $37^{\circ} \mathrm{C}$ in a humidified atmosphere. Cells were solubilised overnight by adding $500 \mu 110 \%$ (w/v) SDS and $0.01 \mathrm{M} \mathrm{HCl}$ until the crystals were completely dissolved. The spectrophotometrical absorbance of the purple-blue formazan dye was determined in an ELISA reader at $595 \mathrm{~nm}$.

DAPI staining. Morphological changes in the cells after treatment with diallylsulfides were observed by phase microscopy and staining of the DNA with the fluorochrome DAPI (4,6-diamidino-2-phenylindole). Cells were seeded on coverslips in $60 \mathrm{~mm}$ dishes to a confluence of $80 \%$. After treatment, the coverslips were rinsed twice with PBS and incubated with $50 \mu 1$ DAPI solution $(2 \mu \mathrm{g} / \mu \mathrm{l}$ methanol) in a humidified chamber for $15 \mathrm{~min}$ at $37^{\circ} \mathrm{C}$. The coverslips were washed $3 \times 5$ min in PBS and $2 \times 5$ min in $\mathrm{H}_{2} \mathrm{O}_{\text {dest. }}$, fixed with a drop of mounting medium and analysed with a fluorescence microscope (excitation: $340 \mathrm{~nm}$ ).

SDS-polyacrylamide gel electrophoresis/Western blot analysis. Proteins were analysed by SDS gel electrophoresis (15). For Western blot analysis, 50-100 $\mu \mathrm{g}$ protein extract were transferred to a PVDF membrane by tank blotting with $20 \mathrm{mM}$ Tris-HCl, pH 8.8, $150 \mathrm{mM}$ glycine as transfer buffer. Membranes were blocked in PBS with $0.1 \%$ Tween-20 and 5\% dry milk for $1 \mathrm{~h}$ at room temperature. The membrane was incubated with the primary antibodies diluted in PBS-Tween-20 with $1 \%$ dry milk either overnight at $4^{\circ} \mathrm{C}$ or for $1 \mathrm{~h}$ at room temperature. The monoclonal mouse antibody cdc $25 \mathrm{C} \mathrm{H6}$
(Santa Cruz) was used in a dilution of 1:500 overnight, the polyclonal rabbit anti PARP antibody (Cell Signalling Technology) 1:1000 overnight, and the rabbit $\alpha$-p53 serum and rabbit GAPDH antibody 1:1000 for $1 \mathrm{~h}$. After washing the membrane with PBS-Tween-20 with $1 \%$ dry milk, it was incubated with the peroxidase-coupled secondary antibody in a dilution of 1:10000 (anti-mouse) or 1:30000 (anti-rabbit) for $1 \mathrm{~h}$ at room temperature. The membrane was washed in PBS-Tween-20 and signals were developed and visualized by the Lumilight system of Roche Diagnostics (Mannheim, Germany).

Cytofluorimetry. For cytofluorimetric analysis cells were washed twice with cold PBS and harvested by trypsinizing. Cells were spun down $\left(250 \mathrm{x} \mathrm{g}, 4^{\circ} \mathrm{C}, 7 \mathrm{~min}\right)$, resuspended in $200 \mu \mathrm{l} \mathrm{PBS}$, fixed by adding $2 \mathrm{ml}$ ice-cold $70 \%$ ethanol and left for at least $30 \mathrm{~min}$ at $-20^{\circ} \mathrm{C}$. After harvesting by centrifugation, cells were resuspended in $800 \mu \mathrm{l}$ PBS. One hundred $\mu \mathrm{l}$ of RNase $(1 \mathrm{mg} / \mathrm{ml})$ and $100 \mu \mathrm{l}$ propidium iodide $(400 \mu \mathrm{g} / \mu \mathrm{l})$ were added and cells were incubated for $30 \mathrm{~min}$ at $37^{\circ} \mathrm{C}$. Cell cycle analysis of the suspension was performed using a FACScan Flow Cytometer (Becton-Dickinson).

\section{Results}

Growth inhibition of cells by diallylsulfides is dependent on the length of the sulphur chain. The first set of experiments aimed at the identification of the most active diallylsulfide against cancer cells. Diallylmono- $\left(\mathrm{Al}_{2} \mathrm{~S}\right)$, diallyldi- $\left(\mathrm{Al}_{2} \mathrm{~S}_{2}\right)$, diallyltri- $\left(\mathrm{Al}_{2} \mathrm{~S}_{3}\right)$ and diallyltetrasulfide $\left(\mathrm{Al}_{2} \mathrm{~S}_{4}\right)$ were either synthesized or obtained commercially and highly purified according to recent literature methods, together with the propyl-analogues (present in onions) and several control compounds, among them 1,6-heptadiene and 1,9-decadiene, the carbon analogues of $\mathrm{Al}_{2} \mathrm{~S}$ and $\mathrm{Al}_{2} \mathrm{~S}_{4}$. Fig. 1a provides the chemical structures of these compounds.

The effect of diallylsulfides on cell viability and proliferation was analysed using the colon carcinoma cell line HCT116 as a suitable model system (14). HCT116 cells were repeatedly treated with $40 \mu \mathrm{M} \mathrm{Al} \mathrm{S}_{2} \mathrm{Al}_{2} \mathrm{~S}_{2}, \mathrm{Al}_{2} \mathrm{~S}_{3}$ or $\mathrm{Al}_{2} \mathrm{~S}_{4}$ in DMSO and with the solvent alone as a negative control. After treatment cell viability was analyzed in the MTT (3[4,5-dimethylthiazol-2-yl]-2,5-diphenyl-tetrazoliumbromide) assay. The results are shown in Fig. 1b. Viability of cells decreased with the length of the sulphur chain. For instance, viability of cells treated with $\mathrm{Al}_{2} \mathrm{~S}_{4}$ for $48 \mathrm{~h}$ was reduced to about $40 \%$ whereas there was hardly any reduction in the case of $\mathrm{Al}_{2} \mathrm{~S}$. Viability of cells not only decreased with the length of the sulphur chain but also with the time of incubation. After 8-h treatment hardly any reduction was detectable for the diallylsulfides whereas $24 \mathrm{~h}$ of $\mathrm{Al}_{2} \mathrm{~S}_{4}$ led to a reduction of the viability to $65 \%$ and a 48 -h treatment to around $40 \%$. In order to analyze whether the diallylsulfides might interfere with the MTT reaction directly we performed the MTT assay in the presence of the different diallylsulfides but in the absence of cell extracts and under otherwise identical conditions as described above. As shown in Fig. 1c there was no direct influence of the diallylsulfides on the MTT assay.

To address the question whether the sulphur chain is indeed responsible for the reduction of cell viability, or if alternative 
a

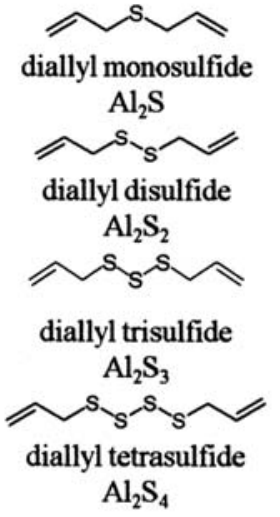

b

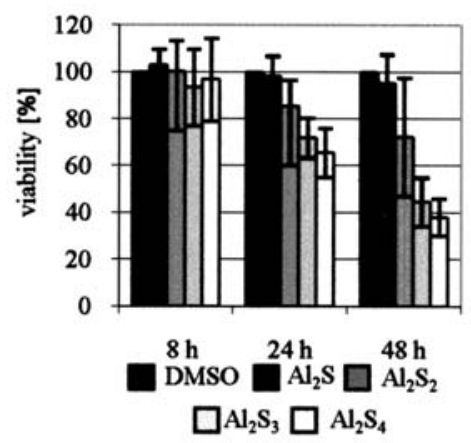

c

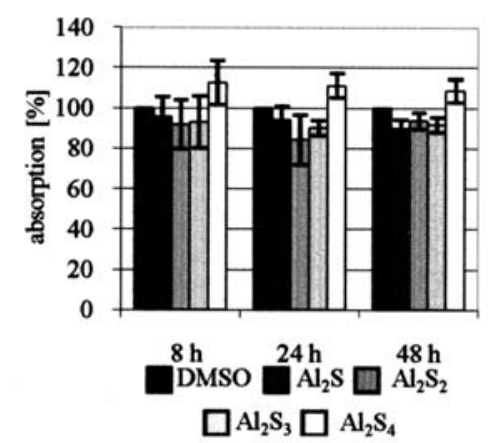

d

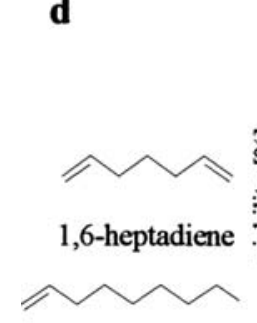

1,9-decadiene

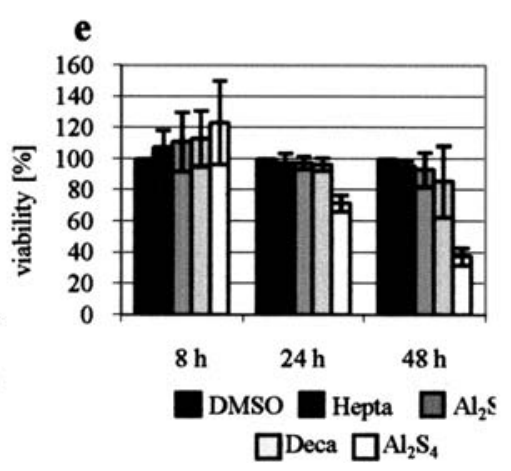

f

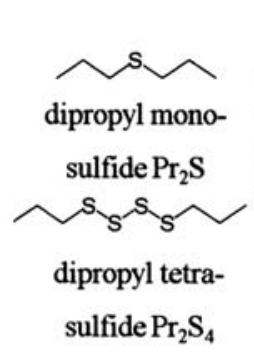

g

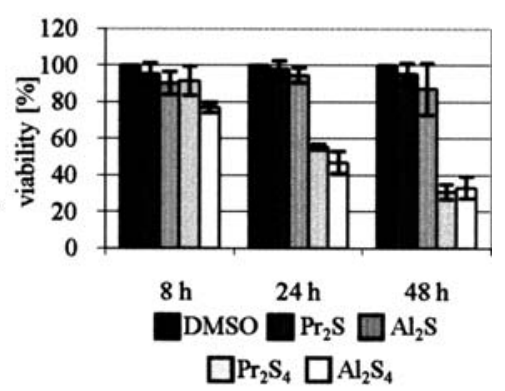

Figure 1. Reduction of HCT116 cell viability by diallylsulfides is dependent on the number of sulphur atoms and independent of C=C double bonds. (a) Structure of diallylsulfides used as part of this study. (b) HCT116 cells were seeded in 24-well plates, treated for 8, 24 or 48 h with diallylpolysulfides and their viability was measured by the MTT assay. Treatment with $0.05 \%$ DMSO (DMSO), $40 \mu \mathrm{M}$ diallylmono- $\left(\mathrm{Al}_{2} \mathrm{~S}\right)$, - $\mathrm{di}^{-}\left(\mathrm{Al}_{2} \mathrm{~S}_{2}\right),-\mathrm{tri}_{-}\left(\mathrm{Al}_{2} \mathrm{~S}_{3}\right)$ or -tetrasulfide $\left(\mathrm{Al}_{2} \mathrm{~S}_{4}\right)$. Values are the average of 5 independent experiments. Bars indicate standard deviation. (c) There is no interference of diallylpolysulfides with MTT. $0.05 \%$ DMSO, $40 \mu \mathrm{M} \mathrm{Al} 2 \mathrm{~S}, \mathrm{Al}_{2} \mathrm{~S}_{2}, \mathrm{Al}_{2} \mathrm{~S}_{3}$, or $\mathrm{Al}_{2} \mathrm{~S}_{4}$ in cell culture medium were incubated without cells for 8, 24 and $48 \mathrm{~h}$ in 24 -well plates and absorption was measured as in the MTT assay. Values are the average of 3 independent experiments. Bars indicate standard deviation. (d) Structures of 1,6-heptadiene und 1,9-decadiene. (e) HCT116 cells were seeded in 24-well plates and treated for 8, 24 or $48 \mathrm{~h}$ with $0.05 \% \mathrm{DMSO}$, or $40 \mu \mathrm{M}$ heptadiene (Hepta), $\mathrm{Al}_{2} \mathrm{~S}$, decadiene (Deca). Viability was measured by the MTT assay. Values are the average of 3 independent experiments. Bars indicate standard deviation. (f) Structures of dipropylmono- and dipropyltetrasulfide. (g) HCT116 cells were seeded in 24-well plates and treated for 8, 24 or $48 \mathrm{~h}$ with $0.05 \%$ DMSO, or $40 \mu \mathrm{M}$ dipropylmonosulfide $\left(\mathrm{Pr}_{2} \mathrm{~S}\right), \mathrm{Al}_{2} \mathrm{~S}$, dipropyltetrasulfide $\left(\mathrm{Pr}_{2} \mathrm{~S}_{4}\right)$, and $\mathrm{Al}_{2} \mathrm{~S}_{4}$. Viability was measured by the MTT assay. Values are the average of 3 independent experiments. Bars indicate standard deviation.

factors, such as the reactivity of allyl-groups play a role, two sets of experiments were conducted. Firstly, the synthetic carbon-analogues of $\mathrm{Al}_{2} \mathrm{~S}$ and $\mathrm{Al}_{2} \mathrm{~S}_{4}$, i.e., 1,6-heptadiene and 1,9-decadiene, were investigated for their influence on the viability of HCT116 cells (Fig. 1d). Cells were treated with $40 \mu \mathrm{M}$ of these compounds for 8, 24 and $48 \mathrm{~h}$, respectively, and then analyzed for cell viability by the MTT assay exactly as described above for the sulphur compounds. Control cells were also treated with $\mathrm{Al}_{2} \mathrm{~S}$ and $\mathrm{Al}_{2} \mathrm{~S}_{4}$. As shown in Fig. 1e neither 1,6-heptadiene nor 1,9-decadiene had any significant influence on cell viability whereas $\mathrm{Al}_{2} \mathrm{~S}_{4}$ reduced cell viability in a very similar manner to the experiments shown in Fig. 1b. These results further support the pivotal role of the polysulfide moiety in biological activity of the diallylsulfides.

Since the diallylsulfides harbour two reactive $\mathrm{C}=\mathrm{C}$-double bonds, which might also be responsible for the reduction of cell viability, a second set of experiments was performed using the corresponding saturated dipropylpolysulfides, namely dipropylmonosulfide $\left(\operatorname{Pr}_{2} \mathrm{~S}\right)$ and dipropyltetrasulfide $\left(\operatorname{Pr}_{2} \mathrm{~S}_{4}\right)$ (Fig. 1f). HCT116 cells were treated with either of the two compounds at the same concentration and under the same conditions as described above. The corresponding MTT assay is shown in Fig. 1g demonstrating that the viability of the cells was reduced by $\operatorname{Pr}_{2} \mathrm{~S}_{4}$ quite similarly to $\mathrm{Al}_{2} \mathrm{~S}_{4}$. There is only a small reduction in the viability of the cells using $\mathrm{Pr}_{2} \mathrm{~S}$ which is in the same range as after treatment with $\mathrm{Al}_{2} \mathrm{~S}$. Thus, these results exclude a major influence of the $\mathrm{C}=\mathrm{C}$ double bond on cell viability.

Taken together, the results point toward special biochemical behaviour of the trisulfide and tetrasulfide, which is in contrast to the mono- and disulfide as well as the carbon analogues, yet appears to be independent from the allyl- or propyl-groups.

Treatment of HCT116 cells with diallyltetrasulfide induces cell cycle arrest and apoptosis. So far we have shown that $\mathrm{Al}_{2} \mathrm{~S}_{3}$ and $\mathrm{Al}_{2} \mathrm{~S}_{4}$ had a most pronounced effect on the viability of HCT116 cells. The reduction in cell viability may be due to a range of biochemical processes such as cell cycle arrest or apoptosis.

Therefore, we treated HCT116 cells with $\mathrm{Al}_{2} \mathrm{~S}_{4}$ (the most active compound) exactly as described above and performed a cell cycle analysis by flow cytometry after treatment for 24 or $48 \mathrm{~h}$. As a control, cells were treated with the solvent DMSO. The results are summarized in Fig. 2. After 24-h 
$\mathbf{a}$

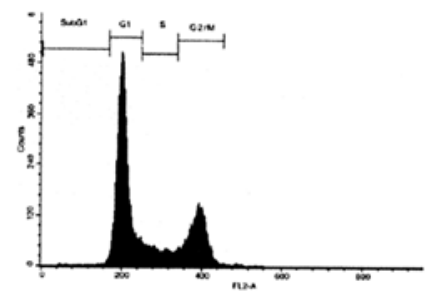

24 h DMSO

b

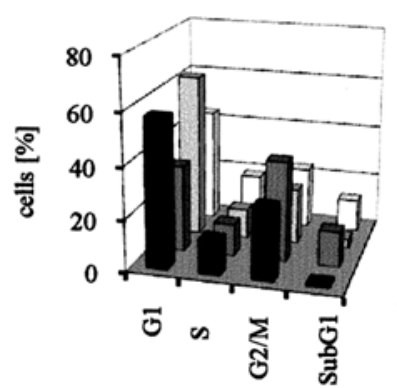

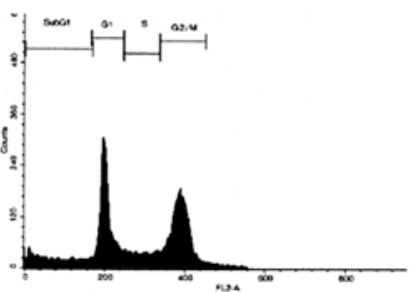

$24 \mathrm{~h} \mathrm{Al}_{2} \mathrm{~S}_{4}$

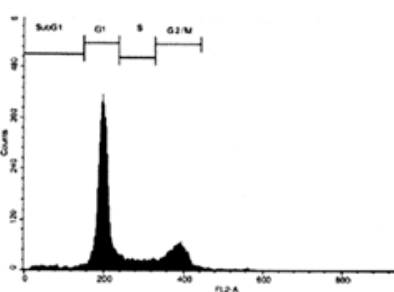

$48 \mathrm{~h}$ DMSO

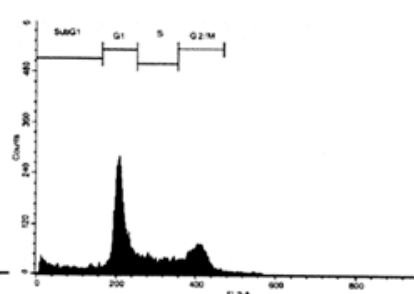

$48 \mathrm{~h} \mathrm{Al}_{2} \mathrm{~S}_{4}$

c

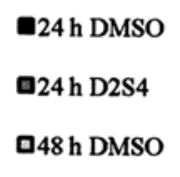

\begin{tabular}{|c|c|c|c|c|}
\hline & $\mathbf{G}_{1}$ & $\mathbf{S}$ & $\mathbf{G}_{\mathbf{2}} / \mathbf{M}$ & SubG $_{1}$ \\
\hline $24 \mathrm{~h} \mathrm{DMSO}$ & $57.39 \%$ & $13.33 \%$ & $27.82 \%$ & $1.04 \%$ \\
\hline $24 \mathrm{~h} \mathrm{Al}_{2} \mathbf{S}_{4}$ & $33.43 \%$ & $12.36 \%$ & $38.63 \%$ & $13.56 \%$ \\
\hline $48 \mathrm{~h} \mathrm{DMSO}$ & $63.04 \%$ & $11.4 \%$ & $21.33 \%$ & $3.48 \%$ \\
\hline $48 \mathrm{~h} \mathrm{Al}_{2} \mathbf{S}_{4}$ & $43.87 \%$ & $18.7 \%$ & $23.51 \%$ & $12.3 \%$ \\
\hline
\end{tabular}

Figure 2. The influence of diallylsulfides on the distribution of cells between the different cell cycle phases. HCT116 cells were treated for 24 or 48 h with $0.05 \%$ DMSO or $40 \mu \mathrm{M}$ diallyltetrasulfide and then analysed by FACS. (a) FACS analysis of the DMSO and $\mathrm{Al}_{2} \mathrm{~S}_{4}$ treated cells. (b) Percentual distribution. (c) Data for (b).

treatment of HCT116 cells with $\mathrm{Al}_{2} \mathrm{~S}_{4}$ an increase of the $\mathrm{G}_{2-}$ phase cell population was observed. Simultaneously, a sub- $G_{1}$ population of cells appeared indicating that cells might have gone into apoptosis.

This interesting finding was explored further. One of the last events in apoptosis is cleavage of poly-ADP-ribose polymerase (PARP) into two fragments with molecular weights of 89 and $27 \mathrm{kDa}$, respectively. Consequently, we have analyzed PARP cleavage after treatment of HCT116 cells with $\mathrm{Al}_{2} \mathrm{~S}, \mathrm{Al}_{2} \mathrm{~S}_{2}, \mathrm{Al}_{2} \mathrm{~S}_{3}, \mathrm{Al}_{2} \mathrm{~S}_{4}$ for 24 and for $48 \mathrm{~h}$. After treatment, cells were extracted and the cell extract was analyzed on an SDS-polyacrylamide gel. After transfer to a PVDF membrane PARP cleavage was measured with an antibody recognising the $116 \mathrm{kDa}$ PARP protein as well as the $89 \mathrm{kDa}$ cleavage product. As shown in Fig. 3, PARP cleavage occurs only after treatment of the cells with $\mathrm{Al}_{2} \mathrm{~S}_{3}$, and $\mathrm{Al}_{2} \mathrm{~S}_{4}$, but not with $\mathrm{Al}_{2} \mathrm{~S}$ and $\mathrm{Al}_{2} \mathrm{~S}_{2}$, which is in agreement with the data obtained with the MTT assay. Thus, from these data we can conclude that at least $\mathrm{Al}_{2} \mathrm{~S}_{3}$ and $\mathrm{Al}_{2} \mathrm{~S}_{4}$ induce apoptosis in HCT116 cells.

Contribution of reactive oxygen species to apoptosis induction by diallylpolysulfides. In order to evaluate the contribution of ROS to the diallyltetrasulfide induced apoptosis we repeated the experiment described above for $\mathrm{Al}_{2} \mathrm{~S}_{4}$ in the presence of two antioxidants, namely ascorbate or $\mathrm{N}$-acetylcysteine (NAC). As a control, we used cells, which were treated with ascorbate or NAC in the absence of $\mathrm{Al}_{2} \mathrm{~S}_{4}$. After incubation for 24 or $48 \mathrm{~h}$ cells were extracted and the cell extract analyzed on an SDS-polyacrylamide gel. Proteins were transferred to a PVDF membrane, which was incubated with an antibody

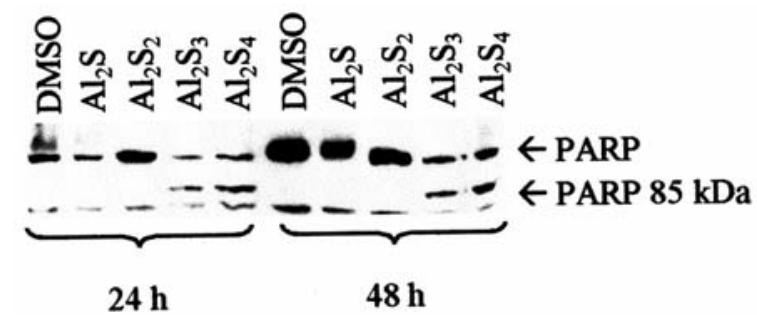

Figure 3. PARP cleavage increases in HCT116 cells after treatment with diallylpolysulfides. HCT116 cells were treated for 24 or $48 \mathrm{~h}$ with $0.05 \%$ DMSO, $40 \mu \mathrm{M} \mathrm{Al} \mathrm{S}_{2} \mathrm{~S}, \mathrm{Al}_{2} \mathrm{~S}_{2}, \mathrm{Al}_{2} \mathrm{~S}_{3}$ or $\mathrm{Al}_{2} \mathrm{~S}_{4}$ and cell extracts were tested for procaspase-3 and PARP cleavage using SDS-polyacrylamide gel electrophoresis and Western blotting. Total protein $(100 \mu \mathrm{g})$ was separated on a $7.5 \%$ SDS polyacrylamide gel, blotted on a PVDF membrane and PARP was detected using the corresponding antibody. GAPDH served as loading control.

recognizing PARP and its cleavage product. As shown in Fig. 4, PARP cleavage was observed for $\mathrm{Al}_{2} \mathrm{~S}_{4}$, but not in the presence of either ascorbate or NAC. Thus, from these results we can conclude that ROS are implicated in $\mathrm{Al}_{2} \mathrm{~S}_{4}$ induced apoptosis. Furthermore, it seems that ROS are actually required for induction of apoptosis by $\mathrm{Al}_{2} \mathrm{~S}_{4}$.

Role of p53 in the diallylpolysulfide induced apoptosis. The apparent involvement of ROS in $\mathrm{Al}_{2} \mathrm{~S}_{4}$ triggered apoptosis of HCT116 cells raises several further questions. p53 is a transcription factor which is often associated with redox processes and - upon redox stress - induces the expression of pro-apoptotic factors and represses the expression of antiapoptotic proteins (10). We have investigated whether p53 is 

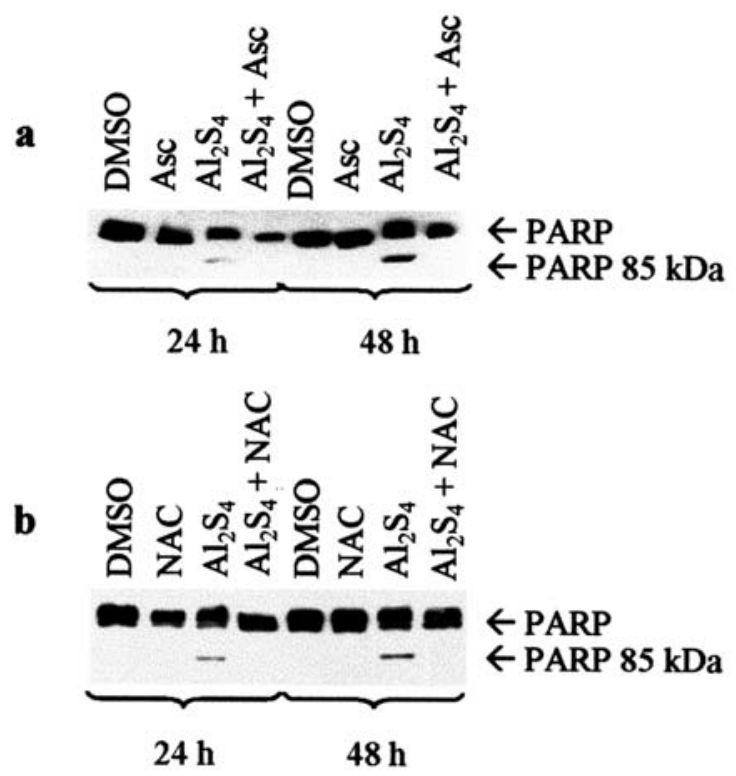

Figure 4. $\mathrm{Al}_{2} \mathrm{~S}_{4}$-induced PARP cleavage in $\mathrm{HCT} 116$ cells is prevented by antioxidants. (a) HCT116 cells treated with $0.05 \%$ DMSO, $100 \mu \mathrm{M}$ ascorbic acid (Asc), $40 \mu \mathrm{M} \mathrm{Al}_{2} \mathrm{~S}_{4}$ or a combination of Asc and $\mathrm{Al}_{2} \mathrm{~S}_{4}$ were examined for PARP cleavage by Western blotting. Total protein $(100 \mu \mathrm{g})$ was separated on a 7.5\% SDS polyacrylamide gel, blotted on a PVDF membrane and PARP cleavage was detected with a PARP specific antibody. (b) as (a) but treatment with $5 \mathrm{mM} \mathrm{NAC}$ instead of $100 \mu \mathrm{M}$ Asc.

activated and thus stabilized by diallylsulfides. HCT116 cells were treated with $\mathrm{Al}_{2} \mathrm{~S}, \mathrm{Al}_{2} \mathrm{~S}_{2}, \mathrm{Al}_{2} \mathrm{~S}_{3}$ and $\mathrm{Al}_{2} \mathrm{~S}_{4}$ as described above. After 24- and 48-h treatments, cells were extracted and the cell extract analyzed on a $12.5 \%$ SDS-polyacrylamide gel. Proteins were transferred to a PVDF membrane which was blotted with a p53 specific polyclonal antibody. The results are shown in Fig. 5a. After treatment of HCT116 cells with $\mathrm{Al}_{2} \mathrm{~S}$ or $\mathrm{Al}_{2} \mathrm{~S}_{2}$ p53 was hardly detectable whereas after treatment with $\mathrm{Al}_{2} \mathrm{~S}_{3}$ or $\mathrm{Al}_{2} \mathrm{~S}_{4}$ a protein band for $\mathrm{p} 53$ was clearly visible indicating a significant increase in the amount of p53 after treatment with $\mathrm{Al}_{2} \mathrm{~S}_{3}$ and $\mathrm{Al}_{2} \mathrm{~S}_{4}$. These results point toward an involvement of p53 in diallylpolysulfide (i.e., $\mathrm{Al}_{2} \mathrm{~S}_{3}, \mathrm{Al}_{2} \mathrm{~S}_{4}$ ) induced apoptosis in $\mathrm{HCT} 116$ cells. In order to analyze whether p53 is actually necessary for the induction of apoptosis by diallylpolysulfides, we studied the effects of these compounds on HCT116 p53\% cells, which differ from HCT116 cells by the absence of p53 (14). Cells were treated with $\mathrm{Al}_{2} \mathrm{~S}, \mathrm{Al}_{2} \mathrm{~S}_{2}, \mathrm{Al}_{2} \mathrm{~S}_{3}$ and $\mathrm{Al}_{2} \mathrm{~S}_{4}$ as described above. Viability of cells was measured by the MTT-assay. As shown in Fig. 5b, cell viability of HCT116 p53 $3^{-/}$cells decreases with increasing length of the sulphur chain of the diallylsulfides, similar to the results obtained for the $\mathrm{p} 53^{+/+}$ cells.

These findings point against a crucial role of p53 in diallylsulfide-induced cell death. We, therefore, further studied HCT116p53\%- cells to see if the observed reduction of viability is associated with induction of apoptosis. As before, cells were treated with the various diallylsulfides and then analyzed for PARP cleavage. As shown in Fig. 5c PARP cleavage was indeed observed for $\mathrm{Al}_{2} \mathrm{~S}_{3}$ and $\mathrm{Al}_{2} \mathrm{~S}_{4}$ treated HCT116 $\mathrm{p} 53^{-/-}$cells, quite similar to the results obtained a

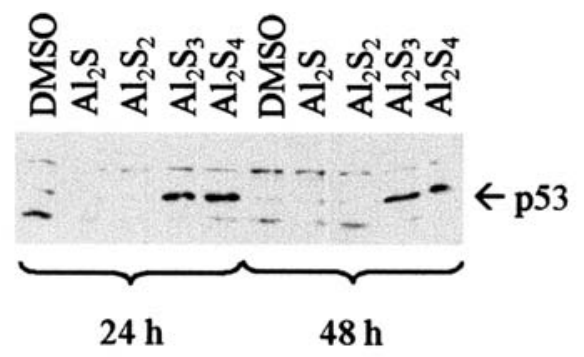

b

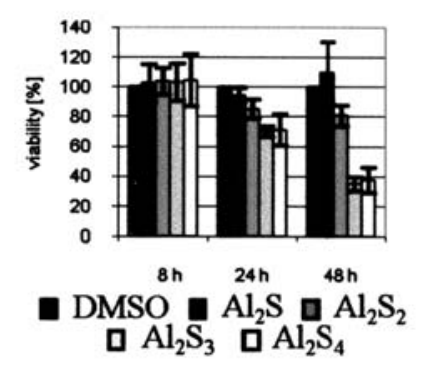

c

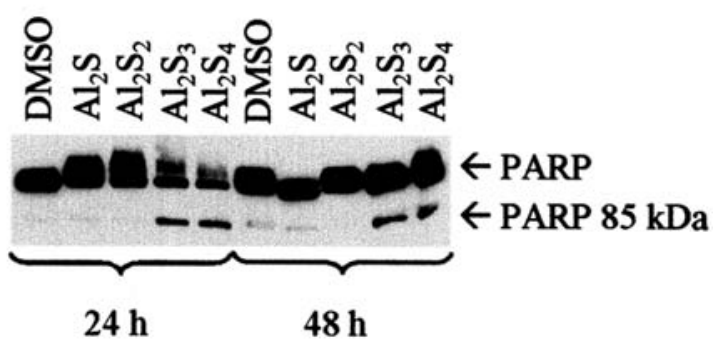

Figure 5. Role of p53 in the induction of apoptosis by diallylpolysulfides. (a) Influence of diallylsulfides on p53 expression in HCT116 cells. HCT116 cells were treated with diallylsulfides and p53 protein expression was studied by Western blotting. Proteins $(50 \mu \mathrm{g})$ were separated on a $12.5 \%$ SDS polyacrylamide gel, blotted on a PVDF membrane and p53 was visualized with antibody $\alpha$-p53. (b) Growth-inhibiting effect of diallylsulfides on HCT116 cells is p53 independent. HCT116p53/- cells were treated with diallylsulfides in 24-well plates and their viability was measured by the MTT assay. Values are the average of 5 independent experiments. Bars indicate standard deviation. (c) Influence of diallylsulfides on PARP cleavage in HCT116 cells is also detectable in HCT116p53 $3^{-/}$cells. HCT116p53/- cells were treated with diallylsulfides or their analogues and PARP cleavage was examined by Western blotting. The protein $(100 \mu \mathrm{g})$ was separated on a $7.5 \%$ SDS polyacrylamide gel, blotted on a PVDF membrane and PARP cleavage was detected with a PARP antibody.

for the $\mathrm{p} 53^{+/+}$cells. Although $\mathrm{p} 53$ levels are affected by the diallylpolysulfides, p53 is dispensable for the induction of apoptosis by $\mathrm{Al}_{2} \mathrm{~S}_{3}$ and $\mathrm{Al}_{2} \mathrm{~S}_{4}$.

Diallylpolysulfides lead to a reduction in the expression of the cell cycle regulating phosphatase cdc25C. This rather surprising finding has led us to investigate an additional signalling pathway which may connect diallylpolysulfides with cell cycle arrest and apoptosis. As part of the present study, we have already shown that at least a partial cell cycle arrest occurs in the $\mathrm{G}_{2}$-phase of the cell cycle (Fig. 2). Since cdc25C is one of the key enzymes responsible for the $\mathrm{G}_{2} \rightarrow \mathrm{M}$ transition (11), it is reasonable to consider whether alterations in the expression of cdc25C might be implicated in diallylpolysulfide induced growth arrest and induction of apoptosis. 
a

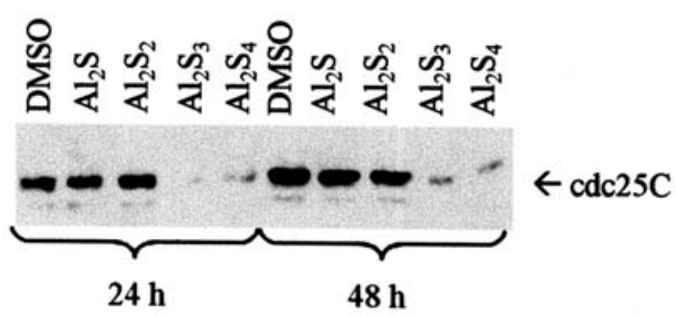

b

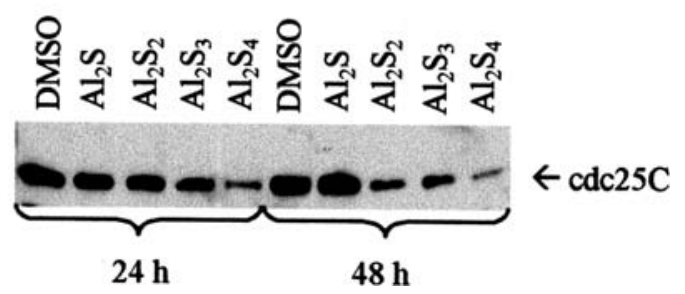

Figure 6. The amount of cdc25C protein decreases after $\mathrm{Al}_{2} \mathrm{~S}_{3}$ and $\mathrm{Al}_{2} \mathrm{~S}_{4}$ treatment in HCT116 and HCT116p53 ${ }^{-/}$cells. (a) HCT116p53wt; and (b) HCT116p53/- cells were treated with diallylsulfides and their analogues and cdc $25 \mathrm{C}$ protein expression was determined by Western blotting. Total protein $(50 \mu \mathrm{g})$ was separated on a $12.5 \%$ SDS polyacrylamide gel, blotted on a PVDF membrane and cdc25C was visualized with the cdc $25 \mathrm{C}$ specific antibody H6.

Cells were therefore treated with diallylsulfides as described above. After 24- and 48-h treatment, cells were harvested and the cell extract analyzed on a $12.5 \%$ SDS-polyacrylamide gel. After blotting to a PVDF membrane, the membrane was incubated with the cdc25C specific antibody H6. As shown in Fig. 6a there was a clear reduction in the amount of cdc25C after treatment of the cells with $\mathrm{Al}_{2} \mathrm{~S}_{3}$ and $\mathrm{Al}_{2} \mathrm{~S}_{4}$, but not with $\mathrm{Al}_{2} \mathrm{~S}$ and $\mathrm{Al}_{2} \mathrm{~S}_{2}$. Thus, cell cycle arrest and induction of apoptosis are associated with a reduction in cdc $25 \mathrm{C}$ expression. Interestingly, similar result was obtained in $\mathrm{p} 53^{-1-}$ HCT116 cells (Fig. 6b) indicating that the reduction in cdc25C levels was not p53-dependent.

\section{Discussion}

In the present study, we have employed chemically synthesized and highly purified diallylsulfides with a chain length from one to four sulphur atoms for a systematic and comparative analysis. The tetrasulfide, $\mathrm{Al}_{2} \mathrm{~S}_{4}$, has rarely been used, possibly because of the difficulties associated with its synthesis and purification. We have used a comparably low concentration of $40 \mu \mathrm{M}$ for all four diallylsulfides. At this concentration, only the trisulfide and the tetrasulfide showed a considerable influence on cell viability whereas the mono- and disulfide had only slight if any effect. Thus, cell viability decreases with increasing length of the sulphur chain and appears to be connected to interchangeable non-carbon-bounded sulphur. The monosulfide appears to be inert, likely because there is no obvious sulphur-sulphur-bond chemistry associated with this molecule. The disulfide may undergo thiol/exchange reactions but disulfides do not possess the ability of sulphur atom transfer, intrinsic to tri- and higher polysulfides.

In contrast, the trisulfides and tetrasulfides exhibit a chemical behaviour suitable for interfering with intracellular redox processes. A contribution of such redox processes was supported by cell culture studies employing the antioxidants ascorbate and NAC. Furthermore, the control experiments employing a range of carbon analogues, propyl-analogues and reduced forms of the diallylsulfides also point into this direction: while the sulphur chain is absolutely essential for activity, the carbon analogues of $\mathrm{Al}_{2} \mathrm{~S}_{3}$ and $\mathrm{Al}_{2} \mathrm{~S}_{4}$ are inactive. Thus, the redox conditions provided by the sulphur chain appears crucial for activity. This is also reflected by the residues attached to the tri- and tetrasulfide chains which appear to be less important: here, we found a similar activity for $\mathrm{Al}_{2} \mathrm{~S}_{4}$ and $\mathrm{Pr}_{2} \mathrm{~S}_{4}$. A possible explanation was the lack of activating electronic effects exerted by the metabolically less stable allyl-group. This similarity in activity once more confirms the special role of the trisulfide and tetrasulfide moieties.

It is known that $\mathrm{Al}_{2} \mathrm{~S}_{3}$ treated gastric cancer cells exhibit a marked decrease in the level of Bcl-2. Using other cell lines, $\mathrm{Al}_{2} \mathrm{~S}$ and $\mathrm{Al}_{2} \mathrm{~S}_{2}$, in contrast to $\mathrm{Al}_{2} \mathrm{~S}_{3}$, seem to cause only a slight decrease in the expression of Bcl-2 and a slight increase in Bax expression, a reflection of the fact that $\mathrm{Al}_{2} \mathrm{~S}$ and $\mathrm{Al}_{2} \mathrm{~S}_{2}$ are only weak inducers of apoptosis (16). This notion has been confirmed in the present study. $\mathrm{Al}_{2} \mathrm{~S}_{3}$ and $\mathrm{Al}_{2} \mathrm{~S}_{4}$ treatment of HCT116 cells results in an elevated level of PARP-cleavage which is a late event in the apoptotic pathway. Moreover, there are clear morphological indications for apoptosis when $\mathrm{Al}_{2} \mathrm{~S}_{3}$ and $\mathrm{Al}_{2} \mathrm{~S}_{4}$ are employed, such as blebbing of the cells and DNA degradation (data not shown).

In the studies presented here, apoptosis and cell cycle arrest appear to be closely related. It has recently been shown that $\mathrm{Al}_{2} \mathrm{~S}_{3}$ treatment of prostate cancer cells results in a significant increase of the $G_{2}$ fraction of cells, with a simultaneous decrease of $\mathrm{G}_{1}$-phase cell population (17). In the present study, we detected only a slight increase in the $\mathrm{G}_{2}$-phase population of cells after 24 -h treatment and after $48 \mathrm{~h}$, pointing towards a $\mathrm{G}_{2}$-arrest and subsequent apoptosis. cdc $25 \mathrm{C}$ is a member of the cdc25 family of phosphatases, which are implicated in cell cycle check-point control. In particular, cdc25C is responsible for $\mathrm{G}_{2} / \mathrm{M}$ transition by dephosphorylation of cdk1 (also known as cdc2). In agreement with a $\mathrm{G}_{2}$-arrest of cells after diallylpolysulfide treatment, we observed a marked decrease in the amount of cdc25C. This effect was especially pronounced after treatment of cells with $\mathrm{Al}_{2} \mathrm{~S}_{3}$ and $\mathrm{Al}_{2} \mathrm{~S}_{4}$, whereas treatment with $\mathrm{Al}_{2} \mathrm{~S}$ or $\mathrm{Al}_{2} \mathrm{~S}_{2}$ had no or only slight effect on the level of cdc25C.

It is known that p53 can act as a suppressor of cdc $25 \mathrm{C}$ and therefore p53 induction might be responsible for the down-regulation of cdc25C (18). After treatment of HCT116 cells with $\mathrm{Al}_{2} \mathrm{~S}_{3}$ and $\mathrm{Al}_{2} \mathrm{~S}_{4}$, but not with $\mathrm{Al}_{2} \mathrm{~S}$ and $\mathrm{Al}_{2} \mathrm{~S}_{2}$ we indeed observed an increase in the level of p53 which might indicate a role of p53 in cell cycle arrest and apoptosis. Cell cycle arrest, down-regulation of cdc25C and induction of apoptosis, however, was also observed in $\mathrm{p} 53^{-/-}$cells. These data show that p53 is clearly dispensable for cell cycle arrest, cdc25C down-regulation and induction of apoptosis. Thus, our results have demonstrated that treatment of cells with diallylpolysulfides resulted in growth arrest and induction of apoptosis. This growth arrest and apoptosis induction is p53 independent and goes along with down-regulation of cdc $25 \mathrm{C}$ and induction of redox processes in the treated cells. 


\section{References}

1. Jacob C, Anwar A and Burkholz T: Perspective on recent developments on sulfur-containing agents and hydrogen sulfide signaling. Planta Med 74: 1580-1592, 2008

2. Jonkers D, van den Broek E, van Dooren I, Thijs C, Dorant E, Hageman G and Stobberingh E: Antibacterial effect of garlic and omeprazole on Helicobacter pylori. J Antimicrob Chemother 43: 837-839, 1999.

3. Milner JA: A historical perspective on garlic and cancer. J Nutr 131: S1027-S1031, 2001.

4. Milner JA: Mechanisms by which garlic and allyl sulfur compounds suppress carcinogen bioactivation. Garlic and carcinogenesis. Adv Exp Med Biol 492: 69-81, 2001.

5. Herman-Antosiewicz A, Powolny AA and Singh SV: Molecular targets of cancer chemoprevention by garlic-derived organosulfides. Acta Pharmacol Sin 28: 1355-1364, 2007.

6. Lan $\mathrm{H}$ and $\mathrm{Lu} \mathrm{YY}$ : Allitridi induces apoptosis by affecting Bcl-2 expression and caspase-3 activity in human gastric cancer cells. Acta Pharmacol Sin 25: 219-225, 2004.

7. Herman-Antosiewicz A and Singh SV: Checkpoint kinase 1 regulates diallyl trisulfide-induced mitotic arrest in human prostate cancer cells. J Biol Chem 280: 28519-28528, 2005.

8. Yuan JP, Wang GH, Ling H, Su Q, Yang YH, Song Y, Tang RJ, Liu Y and Huang C: Diallyl disulfide-induced G2/M arrest of human gastric cancer MGC803 cells involves activation of p38 MAP kinase pathways. World J Gastroenterol 10: 2731-2734, 2004

9. Wu XJ, Kassie F and Mersch-Sundermann V: The role of reactive oxygen species (ROS) production on diallyl disulfide (DADS) induced apoptosis and cell cycle arrest in human A549 lung carcinoma cells. Mutat Res 579: 115-124, 2005.
10. Fridman JS and Lowe SW: Control of apoptosis by $\mathrm{p} 53$. Oncogene 22: 9030-9040, 2003.

11. Hoffmann I: The role of Cdc25 phosphatases in cell cycle checkpoints. Protoplasma 211: 8-11, 2000.

12. Stan SD, Kar S, Stoner GD and Singh SV: Bioactive food components and cancer risk reduction. J Cell Biochem 104: 339-356, 2008.

13. Xiao D and Singh SV: Diallyl trisulfide, a constituent of processed garlic, inactivates Akt to trigger mitochondrial translocation of $\mathrm{BAD}$ and caspase-mediated apoptosis in human prostate cancer cells. Carcinogenesis 27: 533-540, 2006.

14. Bunz F, Dutriaux A, Lengauer C, Waldman T, Zhou S, Brown JP, Sedivy JM, Kinzler KW and Vogelstein B: Requirement for p53 and p21 to sustain $G_{2}$ arrest after DNA damage. Science 282 : 1497-1501, 1998

15. Laemmli UK: Cleavage of structural proteins during the assembly of the head of bacteriophage T 4. Nature 227: 680-682, 1970.

16. Hong YS, Ham YA, Choi JH and Kim J: Effects of allyl sulfur compounds and garlic extract on the expression of Bcl-2, Bax, and p53 in non-small cell lung cancer cell lines. Exp Mol Med 32: $127-134,2000$.

17. Xiao D, Herman-Antosiewicz A, Antosiewicz J, Xiao H, Brisson M, Lazo JS and Singh SV: Diallyl trisulfide-induced $\mathrm{G}(2)-\mathrm{M}$ phase cell cycle arrest in human prostate cancer cells is caused by reactive oxygen species-dependent destruction and hyperphosphorylation of Cdc25C. Oncogene 24: 6256-6268, 2005

18. Krause K, Haugwitz U, Wasner M, Wiedmann M, Mössner J and Engeland $\mathrm{K}$ : Expression of the cell cycle phosphatase $\mathrm{cdc} 25 \mathrm{C}$ is down-regulated by the tumor suppressor protein $\mathrm{p} 53$ but not by p73. Biochem Biophys Res Commun 284: 743-750, 2001. 